\title{
Proof of concept for a biochemical test that differentiates between heat-treated and non-heat- treated food products
}

\author{
I.I. Iline, M.A. Novoselov and C.B. Phillips \\ AgResearch, Lincoln, Private Bag 4749, Christchurch 8140, New Zealand. \\ Corresponding author: ilia.iline@agresearch.co.nz
}

\begin{abstract}
Quarantine authorities often deal with imported food products containing ingredients of animal origin that can carry biosecurity hazards such as animal diseases. The New Zealand Ministry for Primary Industries (MPI) developed an Import Health Standard to manage this risk. The standard states that products must be heated to a specified temperature for a specified time (e.g. $110^{\circ} \mathrm{C}$ for $40 \mathrm{~min}$ ) within hermetically sealed containers. However, it can be difficult to verify that products have been properly heat-treated, and a quick, easily-used test would assist with verification. Possible targets of such a test are enzymes that are inactivated by high temperatures. This paper describes a modified electrophoretic gel stain recipe for glucose-6-phosphate isomerase (GPI) that enables testing of samples in tubes. In these experiments, non-heat-treated food products rapidly produced a coloured dye after being mixed with stain, but heat-treated products did not. Some imported foods intercepted by MPI were also evaluated. There is potential to develop similar tests for use on plant products and/or organisms associated with plant products to verify heat treatment has taken place.
\end{abstract}

Keywords heat treatment, quarantine, biochemical colorimetric assay, glucose-6-phosphate isomerase, heat treatment efficacy.

\section{INTRODUCTION}

Imported food products that contain ingredients of animal origin can pose biosecurity and health risks. The New Zealand Ministry for Primary Industries (MPI) developed an Import Health Standard to manage these risks. To meet the standard, products must be heated to a specified temperature for a specified time (e.g. $110^{\circ} \mathrm{C}$ for 40 minutes, or $121^{\circ} \mathrm{C}$ for 3 minutes) within hermetically sealed containers (http://www. biosecurity.govt.nz/imports/animals/standards/ ediproic.all.htm). Some plant products can also be heat-treated to mitigate biosecurity risks (Lurie
1998; Myers et al. 2009). However, it is usually difficult for MPI to verify that a product has been properly heat-treated, and a quick, easily-used test would assist with verification.

The temperature at which enzymes become inactivated is an important consideration for developing a test. Relatively high temperatures like those specified in the MPI standard should inactivate nearly all enzymes, so the presence of enzyme activity in a sample would correctly indicate it had not been properly heat-treated (i.e. a true positive). However, if the enzyme became 
inactivated at a low temperature (e.g. $50^{\circ} \mathrm{C}$ ), then enzyme activity could also be absent from samples that had not been treated to standard (i.e. a false negative). Therefore, the best targets are enzymes that are inactivated at relatively high temperatures (Twomey \& Doonan 1997; Sharma et al. 2009; Rankin et al. 2010) near to those specified in the MPI standard.

Seven enzymes were recently found to show postmortem activity in four insect species (I. Iline, unpublished data). The most stable of these was glucose-6-phosphate isomerase (GPI, EC No 5.3.1.9), which was detected up to 6 months post-mortem. It is possible to develop quick, easy-to-use tests by exploiting enzyme-driven staining reactions to produce coloured dye in a sample macerated in a plastic tube (Phillips et al. 2013). This paper demonstrates that a test based on a stain for GPI has potential for distinguishing between heat-treated and non-heat-treated food products that contain animal proteins.

\section{MATERIALS AND METHODS Staining method}

The stain used was a modified version of a gel electrophoresis stain for GPI that relies on reduction of a tetrazolium salt, methyl thiazolyl tetrazolium (MTT), to produce a purple formazan dye (Manchenko 2003). The modifications tested in the present study included substituting phenazine methosulfate (PMS) with 1-methoxy-5-methylphenazinium methyl sulfate (mPMS), using Tris-acetate-EDTA (TAE) buffer instead of Tris- $\mathrm{HCl}$, reducing the amount of fructose-6-phosphate $(0.2 \mathrm{mg} / \mathrm{ml})$, and adding 6-phosphogluconate dehydrogenase $(2 \mathrm{U} / \mathrm{ml})$ and $0.2 \%$ Triton $\mathrm{X}-100$. This stain is yellow due to the presence of MTT.

Two methods of mixing samples with stain solution were used. With birds' nests (Table 1, products $16,25,26$ ), samples were macerated in staining solution at a ratio of stain volume to sample weight of $5 \mu \mathrm{l}: 1 \mu \mathrm{g}$. For all other products (Table 1), samples were first macerated in $0.1 \mathrm{M}$ TAE buffer $\mathrm{pH} 7.80$, then the resulting supernatant was mixed with an equal volume of stain. The final ratios of stain volume $(\mu \mathrm{l})$ to weight $(\mu \mathrm{g})$ were 10:1 for processed products (Table 1, products 4, 12, 14, 15, 17-24, 27), and 20:1 for unprocessed products (Table 1, products 1-3, 5-11, 13). Enzyme activity tended to be higher in unprocessed products, hence a more dilute stain solution was used so that the rate at which the samples became stained was similar for processed and unprocessed foods. Assays were conducted in $0.2 \mathrm{ml}$ microtubes (Axygen, California, USA, thin wall clear, PCR-02-C).

Ten minutes after adding the stain solution, the colour reaction was visually assessed and photos were taken as described below. Production of purple colouration indicated the presence of active enzymes in a sample (i.e. not heattreated), and its absence indicated no enzyme activity (i.e. heat-treated). To obtain quantitative data, image analysis software (ImageJ v. 1.29, http://rsbweb.nih.gov/ij) was used to measure the colour of stain supernatants in $0.2 \mathrm{ml}$ tubes. This involved positioning tubes upright against the illuminated vertical face of a fluorescent light box, then digitally photographing them in lateral view, $10 \mathrm{~min}$ after starting each assay. The image was opened in ImageJ, its background subtracted using a rolling ball radius of 300 pixels, a rectangle of stain, free of tissue and precipitate, was selected within each tube and mean pixel values for the red, green and blue channels were measured using ImageJ's 'RGB Histogram' macro (Phillips et al. 2013).

The mean pixel value of the blue channel divided by the mean pixel value of the green channel $(B: G)$ provided a useful numerical representation of the visual observations of colour changes, so it was used to help compare and describe results. B:G increased as the intensity of the purple colour of MTT formazan increased. Formazan production was visually evident at $\mathrm{B}: \mathrm{G} \geq 0.96$ (see Results). Means are given \pm 1 standard error.

\section{Food products tested}

The food products tested are listed in Table 1 . They were either purchased from a supermarket (samples 1-13) or intercepted by MPI at the New Zealand border (products 14-27). Before testing, birds' nests, salami and biltong, were stored at 
ambient room temperature (products 4, 12, 16, 25 and 26), and the remainder were stored in a freezer.

\section{GPI inactivation temperature}

To estimate the temperature at which GPI became inactivated, raw pork, raw chicken and raw terakihi fish were purchased from a supermarket (Table 1, products 1-3). Five 30$60 \mathrm{mg}$ subsamples of each product were placed into the bottom of sealed $2 \mathrm{ml}$ microtubes, and heated for $40 \mathrm{~min}$ in a Labnet digital dry bath. One set of five subsamples of each type of meat was heated at one of the following temperatures: $60,70,80,90,100$ or $110^{\circ} \mathrm{C}$. Additional sets of five subsamples of each meat were not heated and served as controls. The subsamples were then tested as described above.

Distinguishing between heat-treated and nonheat-treated products

All products were subsampled and tested at least twice. They were initially tested in their original state (' $\mathrm{B}: \mathrm{G}$ ratio from test 1 ' in Table 1 ). Then, one 30-100 mg subsample of each product was placed into the bottom of a $2 \mathrm{ml}$ microtube, heated for $40 \mathrm{~min}$ in a Labnet digital dry bath at $110^{\circ} \mathrm{C}$ (i.e. as per the MPI standard), and retested (' $\mathrm{B}: \mathrm{G}$ ratio from test 2 ' in Table 1). This second test provided a check that the assay always gave negative results for products that had been heat-treated to the MPI standard.

\section{Enzyme stability during product storage}

To check if enzyme activity changed during storage, 8 of the 27 products (products 5, 6, 8-10, 16, 25 and 26 in Table 1) were stored for up to 4 years, then tested ('B:G ratio from test 3 ' in Table 1 ).

\section{RESULTS}

\section{GPI inactivation temperature}

Enzyme activity declined as temperature increased in all three products (Figure 1). However, minimum inactivation temperatures differed between the products; terakihi fish lost enzyme activity at $70^{\circ} \mathrm{C}$, chicken at $100^{\circ} \mathrm{C}$, and pork at $110^{\circ} \mathrm{C}$ (Figure 1). Enzyme activities in unheated controls are shown in Table 1 (products 1-3, 'B:G ratio from test 1').

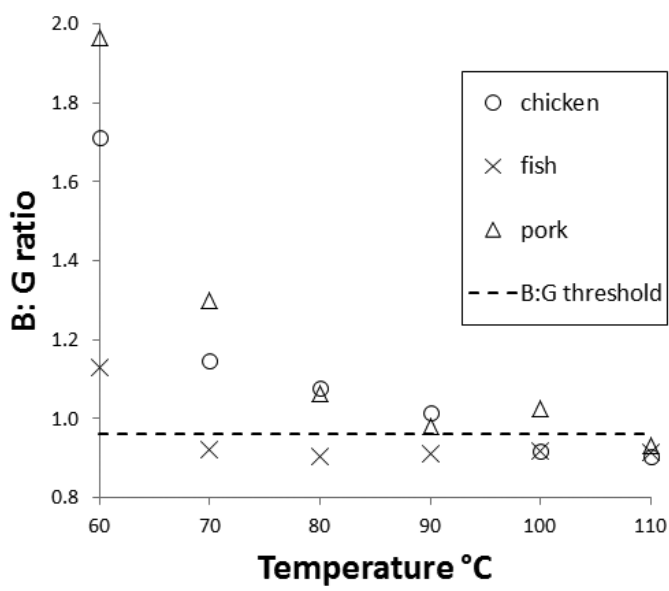

Figure 1 Glucose-6-phosphate isomerase (GPI) activity in pork, chicken and terakihi fish heated at different temperatures (five samples in each treatment). The intensity of the colour reaction was measured by $\mathrm{B}: \mathrm{G}$ ratio.

Standard errors were not included in Figure 1 because they were too small to show clearly on the graph. For example, the largest standard error was for the B:G ratio estimated for pork at $60^{\circ} \mathrm{C}$ and was only \pm 0.12 .

\section{Distinguishing between heat-treated and non- heat-treated products}

Results of the GPI tests are summarised in Table 1. The supermarket products, which were all raw, always gave strong colour reactions before being heat-treated (see ' $\mathrm{B}: \mathrm{G}$ ratio from test 1' in Table 1). The mean B:G ratio of these tests was $4.10 \pm 0.28$. However, none of the supermarket products showed enzyme activity (B:G > 0.96) after heat treatment (see ' $\mathrm{B}: \mathrm{G}$ ratio from test 2' in Table 1; mean B:G ratio $0.89 \pm 0.02$ ). Two of the MPI products were also uncooked (Table 1 , products 14 and 15), and both of these also showed positive colour reactions in the first test characteristic of a non-heat-treated product. After being heat-treated, they gave negative reactions in the second test.

The remaining twelve MPI products (Table 1, products 15-27) had unknown treatment histories. Four of these gave negative results 
Table 1 Summary of results from glucose-6-phosphate isomerase (GPI) tests of local and imported food products. Test 1 was conducted with the products in their original state, test 2 after applying a heat treatment that was compliant with the MPI standard, and test 3 was conducted 4 years after test 1.

\begin{tabular}{|c|c|c|c|c|c|c|c|}
\hline \# & Product name & Origin & Treatment & $\begin{array}{c}\text { B:G ratio } \\
\text { from test } \\
1\end{array}$ & $\begin{array}{c}\text { Conclusion from } \\
\text { test } 1\end{array}$ & $\begin{array}{c}\text { B:G ratio } \\
\text { from test } \\
2\end{array}$ & $\begin{array}{l}\text { B:G } \\
\text { ratio } \\
\text { from } \\
\text { test } 3\end{array}$ \\
\hline 1 & Chicken $^{1}$ & NZ supermarket & uncooked & $3.14 \pm 0.17$ & non-heat-treated & $0.90 \pm 0.00$ & - \\
\hline 2 & Terakihi fish ${ }^{1}$ & NZ supermarket & uncooked & $4.77 \pm 0.16$ & non-heat-treated & $0.91 \pm 0.00$ & - \\
\hline 3 & Pork $^{1}$ & NZ supermarket & uncooked & $5.52 \pm 0.17$ & non-heat-treated & $0.93 \pm 0.00$ & - \\
\hline 4 & Biltong (beef) & NZ supermarket & uncooked & 1.94 & non-heat-treated & 0.55 & - \\
\hline 5 & Pork & NZ supermarket & uncooked & 2.80 & non-heat-treated & 0.91 & 1.55 \\
\hline 6 & Pork & NZ supermarket & uncooked & 2.92 & non-heat-treated & 0.89 & 1.54 \\
\hline 7 & Red cod & NZ supermarket & uncooked & 2.97 & non-heat-treated & 0.88 & - \\
\hline 8 & Pork & NZ supermarket & uncooked & 3.04 & non-heat-treated & 0.91 & 1.48 \\
\hline 9 & Pork & NZ supermarket & uncooked & 3.28 & non-heat-treated & 0.90 & 1.59 \\
\hline 10 & Pork & NZ supermarket & uncooked & 3.30 & non-heat-treated & 0.89 & 1.60 \\
\hline 11 & Beef & NZ supermarket & uncooked & 3.63 & non-heat-treated & 0.88 & - \\
\hline 12 & Danish salami & NZ supermarket & uncooked & 6.35 & non-heat-treated & 0.84 & - \\
\hline 13 & Prawn & NZ supermarket & uncooked & 7.40 & non-heat-treated & 0.83 & - \\
\hline 14 & Pork sausage & Canada & uncooked & 1.01 & non-heat-treated & 0.86 & - \\
\hline 15 & Pork cutlets & Korea & uncooked & 1.08 & non-heat-treated & 0.88 & - \\
\hline 16 & $\begin{array}{l}\text { Bird's nest } \\
\text { with agar }\end{array}$ & China & uncertain & 0.61 & heat-treated & 0.63 & 0.59 \\
\hline 17 & Dried beef & China & uncertain & 0.73 & heat-treated & 0.82 & - \\
\hline 18 & Dried pork & China & uncertain & 0.86 & heat-treated & 0.85 & - \\
\hline 19 & $\begin{array}{c}\text { Vienna } \\
\text { sausage }\end{array}$ & Korea & uncertain & 0.91 & heat-treated & 0.92 & - \\
\hline 20 & $\begin{array}{c}\text { Vienna } \\
\text { sausage Gold }\end{array}$ & Korea & uncertain & 1.05 & non-heat-treated & 0.92 & - \\
\hline 21 & $\begin{array}{l}\text { Dongwon } \\
\text { sausage }\end{array}$ & Korea & uncertain & 1.06 & non-heat-treated & 0.78 & - \\
\hline 22 & $\begin{array}{l}\text { Traditional } \\
\text { pressed ham }\end{array}$ & Korea & uncertain & 1.19 & non-heat-treated & 0.92 & - \\
\hline 23 & Frank sausage & Korea & uncertain & 1.49 & non-heat-treated & 0.87 & - \\
\hline 24 & Kimbab ham & Korea & uncertain & 1.62 & non-heat-treated & 0.84 & - \\
\hline 25 & Bird's nest & China & uncertain & 1.95 & non-heat-treated & 0.65 & 1.41 \\
\hline 26 & $\begin{array}{l}\text { Bird's nest } \\
\text { with agar }\end{array}$ & China & uncertain & 2.28 & non-heat-treated & 0.63 & 1.56 \\
\hline 27 & $\begin{array}{l}\text { Cutlets (pork, } \\
\text { chicken) }\end{array}$ & Korea & uncertain & 2.76 & non-heat-treated & 0.92 & - \\
\hline
\end{tabular}

${ }^{1}$ Five samples of the product were tested. 
(no colour change) both in the first test (Table 1 , products $16-19$, mean $\mathrm{B}: \mathrm{G}$ ratio $0.78 \pm 0.07$ ) and in the second test (mean B:G ratio $0.80 \pm$ 0.06 ), thus they had probably been heat-treated before test 1 . The other eight MPI products gave positive colour reactions in the first test (Table 1 , products $20-27$, mean $\mathrm{B}: \mathrm{G}$ ratio $1.68 \pm 0.22$ ), and negative results in the second test (mean B:G ratio $0.82 \pm 0.04$ ), so they probably had not been heat-treated before test 1 .

\section{Enzyme stability during product storage}

All eight products that were stored for 4 years and then re-tested showed minor declines in B:G ratio. However, the seven products that originally showed enzyme activity still tested positive after storage (Table 1, 'B:G ratio from test 3').

\section{DISCUSSION}

Comparisons between untreated and heattreated products clearly demonstrated there is good potential to produce a GPI-based assay for assessing biosecurity risks from imported foods. Positive assay results were obtained from all untreated products, and negative assay results were obtained from all products treated to the MPI standard. The assay remained reliable when tested on products that had been stored for long periods. GPI is present in plants as well as animals, so the assay may also have potential to verify that plant products, or organisms associated with plant products, have been heat treated. Hence, proof of concept has been achieved.

It is theoretically possible that some nonenzymatic compounds could cause reduction of MTT to formazan (Csönge et al. 2002; Johno et al. 2010), thus producing false positives in the tests when active enzymes were absent. To check for this, subsamples of all control and heat-treated products were tested for the presence of formazan in a solution that only contained MTT and mPMS. No formazan was detected, so all of the positive assay results were due to the presence of active enzymes. However, the possibility of nonenzymatic production of formazan would need to be considered when testing a broader range of products than was sampled in the present study.
The assay was found to be sufficiently sensitive for use even with dry products that contained relatively little protein such as birds' nests. However, samples like these probably require maceration directly in staining solution to minimise dilution.

The temperature at which GPI became inactivated in pork corresponded well with the MPI standard, but GPI in chicken and fish was inactivated at lower temperatures. The temperature at which enzymes become inactivated may be influenced by the presence of particular compounds (Muramatsu \& Nosoh 1971; Burnette \& Flich 1978), and this aspect of the assay would require further investigation. How the performance of the assay might be influenced by products that contain a mixture of meats (e.g. product 27 in Table 1) also needs assessment. Probably the most practical approach to implementing the assay would be to validate it for use with particular products in an incremental way, starting with those considered highest priority by MPI.

To our knowledge, GPI has not previously been used in assays for monitoring heat treatments. Townsend \& Blankenship (1987, 1988) used the APIZYM system (API Laboratory Products Ltd, Philpot House, Rayleigh, Essex) to screen a range of enzymes in meat and poultry after heat treatment. They found leucine aminopeptidase to be a useful marker of heat treatment, but it was inactivated at a lower temperature than GPI was in the present experiment.

\section{ACKNOWLEDGEMENTS}

We thank Zoran Sinovcic (MPI) for providing the food products intercepted at the border. Development of the biochemical assay was supported by the Better Border Biosecurity (B3) programme (www.b3nz.org) funded by MBIE through AgResearch Core Funding.

\section{REFERENCES}

Burnette FS, Flich GJ Jr 1978. Activity and resistance to thermal inactivation of peroxidase in the blue crab (Callinectes sapidus). Journal of Food Science 43: 31-34. 
Csönge L, Bravo D, Newman-Gage H, Rigley T, Conrad EU, Bakay A, Strong DM, Pellet S 2002. Banking of osteochondral allografts. Part I. Viability assays adapted for osteochondrol and cartilage studies. Cell and Tissue Banking 3: 151-159.

Johno H, Takahashi S, Kitamura M 2010. Influences of acidic conditions on formazan assay: A cautionary note. Applied Biochemistry and Biotechnology 162: 1529-1535.

Lurie S 1998. Postharvest heat treatments. Postharvest Biology and Technology 14: 257-269.

Manchenko GP 2003. Handbook of Detection of Enzymes on Electrophoretic Gels - 2nd ed. CRC Press LLC, Boca Raton, FL, USA. 553 p.

Muramatsu N, Nosoh Y 1971. Purification and characterization of glucose-6-phosphate isomerase from Bacillus stearothermophilus. Archives of Biochemistry and Biophysics 144: 245-252.

Myers SW, Fraser I, Mastro VC 2009. Evaluation of heat treatment schedules for emerald ash borer (Coleoptera: Buprestidae). Journal of Economic Entomology 102: 2048-2055.

Phillips CB, Iline II, Novoselov M, Richards NK, McNeill MR 2013. Development and validation of a quick, easily used biochemical assay for evaluating the viability of small immobile arthropods. Journal of Economic Entomology 106: in press.
Rankin SA, Christiansen ALW, Banavara DS, Lopez-Hernandez A 2010. Invited review: The application of alkaline phosphatase assays for the validation of milk product pasteurization. Journal of Dairy Science 93: 5538-5551.

Sharma R, Kaur S, Rajput YS. 2009. Activity and thermal stability of indigenous enzymes in cow, buffalo and goat milk. Milchwissenschaft 64: 173-175.

Townsend WE, Blankenship LC 1987. Assessment of previous heat treatment of laboratory heat-processed meat and poultry using a commercial enzyme system. Journal of Food Science 52: 1445-1448.

Townsend WE, Blankenship LC 1988. Assessment of previous heat treatment given to semicommercially and commercially prepared meat and poultry products using the "APIZYM" system. Journal of Food Science 53: 649-651

Twomey CM, Doonan S 1997. A comparative study of the thermal inactivation of cytosolic and mitochondrial aspartate aminotransferases. Biochimica et Biophysica Acta 1342: 37-44. 